\title{
Mengkaji ulang hukum acara perceraian di pengadilan agama
}

\author{
Abdullah Gofar \\ Fakultas Hukum Universitas Sriwijaya Palembang \\ E-mail:abdullabgofar12@yahoo.co.id
}

Procedural legal issues of religion in resolving divorce cases still using prosedural of civil law (H.I.R and R.B.Bg). Size of formal mechanistic truths, so the more important aspects of the divorce prosess legal certainty and axpediancy, however, rule out the maslahat aspect, in accordance with the value of Islamic law. The research objective is to examine the application of civil law in the process of divorce in western religious courts that have shifted, so the procedural law can not be used to answer problems in areas of family law. Research methodology using normative judicial approach to secondary data laws and judicial decisions of religion. Procedural law religious marriage in Islamic can not be measurred by mere formal proof, but there are aspects of the sacred reality can not be measured from a mere formal proof. Enforcement of civil law aspect "mutatis mutandis", it did not touch the substantial aspects the "mashlahat" aspect. Implications of the case, that the rule of law in judicial process likely to lead to desecularization religious law of Islamic, not the desration of Islamic law.

Permasalahan hukum acara peradilan agama dalam menyelesaikan perkara perceraian masih menggunakan hukum acara perdata Barat yakni H.I.R dan R.Bg. Ukuran kebenaran bersifat formal mekanistik, sehingga proses perceraian lebih mementingkan aspek kepastian hukum dan kemanfaatan, namun mengesampingkan aspek kemaslahatan, sesuai dengan nilai hukum Islam. Tujuan penelitian adalah untuk mengkaji pemberlakuan hukum acara perdata Barat dalam proses perceraian di peradilan agama yang telah bergeser, sehingga hukum acara peradilan yang digunakan tidak dapat menjawab masalah di bidang hukum keluarga. Metodologi penelitian menggunakan metode yuridis normatif dengan pedekatan data sekunder UU dan putusan pengadilan agama. Hukum acara peradilan agama di bidang perkawinan Islam, tidak dapat diukur dari pembuktian formal semata, melainkan terdapat aspek sakral yang kenyataannya tidak dapat diukur dari pembuktian formal belaka. Pemberlakuan hukum acara perdata Barat secara mutatis mutandis, ternyata tidak menyentuh aspek substansial, yakni aspek mashlahat. Implikasi terjadi, bahwa proses penegakan hukum di peradilan agama cenderung mengarah pada desekularisasi hukum Islam, bukan desakralisasi hukum Islam.

Keywords: Procedural law; Divorce; Religious court 
ljtihad, Jurnal Wacana Hukum Islam dan Kemanusiaan, Volume 13, No. 1, Juni 2013: 105-124

\section{Pendahuluan}

Keberadaan peradilan agama sebagai subsistem peradilan Indonesia, tidak terlepas dari perkembangan sejarah. Sejak tanggal 30 Juli 2004 secara organisasi kelembagaan, finansial serta teknis mengadili, peradilan agama telah berada di bawah dalam satu wadah tunggal di bawah kekuasaan Mahkamah Agung. Penyatuan dan perubahan tersebut belum menyentuh pada substansi Undang-Undang (UU) hukum acara peradilan agama sebagai pedoman dan panduan menyelesaikan setiap perkara di Pengadilan Agama (PA).

Peradilan agama dan dengan penamaan lain seperti Mahkamah Syariah sejak awal pembentukan hingga pada masa pemerintahan Hindia Belanda, peradilan agama sering disebut sebagai Raad Agama atau Priesterraad. Peradilan agama sangat lekat dengan stigma negatif (a mark of disgrace or shame) sebagai Kantoor Voor Inlansche Zaken yang tidak dapat dilepaskan dari politik dan ide yang diciptakan pemerintah Hindia Belanda. Meskipun stigma Kantoor Voor Inlansche Zaken telah bergeser, seiring dengan perubahan pandangan dan struktur peradilan di Indonesia, tetapi perhatian untuk membuat UU hukum acara khusus tentang peradilan agama, termasuk hukum acara di bidang perceraian belum mendapat perhatian serius. Peradilan agama telah memberi sumbangsih yang cukup besar terhadap perkembangan hukum dan peradilan di Indonesia, baik sebelum maupun setelah kemerdekaan hingga pasca orde Reformasi. Berdasarkan data Kementerian Agama dari jumlah perkara yang masuk ke pengadilan di seluruh peradilan di Indonesia, di atas 50\% adalah perkara perceraian yang diajukan ke Pengadilan Agama. Sedangkan perkara kriminal di Peradilan Umum hanya 33\%. Pada tahun 2009 jumlah perkara yang masuk ke P.A 257.798 perkara, sedangkan Peradilan Umum berjumlah 202.754. Fenomena tersebut menuntut pembenahan aspek substansi UU hukum acara yang digunakan di dalam memeriksa perkara perceraian. Peradilan agama sebagai peradilan khusus mempunyai karakteristik khusus pula. Tatacara pengajuan perkara, pemeriksaan serta putusan harus menggunakan hukum acara khusus dan tidak disamakan dengan hukum acara perdata Barat. Akibat penggunaan tersebut, telah menggiring penyelesaian hukum perceraian orang Islam mengikuti tahapan dan hukum Barat yang lebih mementingkan kepastian dan kemanfaatan hukum, tetapi mengkesampingkan aspek kemaslahatan berdasarkan nilai keislaman. 
Politik hukum lahirnya UU tentang peradilan agama UU No. 7 Tahun 1989, patut diapresiasi sebagai pencapaian perjuangan yang patut disyukuri. Artinya usaha memformalisasi hukum peradilan agama berbentuk UU telah membuahkan hasil. Secara kelembagaan peradilan agama telah mempunyai dasar hukum tertulis, sejajar dengan lembaga peradilan lain. Kewenangan peradilan agama lebih nyata diatur di dalam Pasal 49 UU No.7 Tahun 1989 dan perubahannya dalam UU No.3 Tahun 2006, terakhir diubah dengan UU No. 50 Tahun 2009. Selain itu usaha memformalkan hukum materiil secara bertahap telah dan sedang dilakukan.

Persoalannya terletak pada hukum acara, dimana peradilan agama dalam proses perkara perceraian yang masih menggunakan hukum acara perdata Barat. Rumusan Pasal 54 UU No.7 Tahun 1989 tentang Peradilan Agama, menegaskan hukum acara yang berlaku di lingkungan peradilan agama adalah hukum acara yang berlaku di lingkungan peradilan umum sepanjang tidak diatur di dalam UU ini (Mardani: 2009: 14). Ketentuan tersebut menegaskan proses penyelesaian perkara di peradilan agama, menggunakan hukum acara dan hukum pembuktian berdasarkan H.I.R dan R.Bg, sepanjang tidak diatur secara tegas di dalam UU No. 7 tahun 1989 tentang Peradilan Agama. Amanat yang terkandung di dalam rumusan Pasal 54 tersebut, pertama, bahwa penggunaan hukum acara dan sistem pembuktian hukum Barat bersifat temporer. Kedua, penggunaan sistem pembuktian dan hukum acara perdata Barat tidak mendominasi, ketika mengadili perkara yang punya kekhususan terutama perkara perceraian. Ketiga, prinsip dan asas hukum Islam sebagai dasar penyelesaian perkara tetap diutamakan. Ketentuan hukum perdata Barat dapat digunakan sepanjang tidak bertentangan dengan hukum Islam.

Mencermati data di setiap Pengadilan Agama, menunjukkan jumlah perkara yang terdaftar setiap tahun terus meningkat di atas angka 10\%. Umumnya perkara yang diajukan adalah perkara perceraian, baik yang berbentuk permohonan talaq maupun cerai gugat. Jika diasumsikan angka pernikahan mencapai 2,5 juta pasangan, maka hampir 250.000 pasangan melakukan perceraian di peradilan agama di seluruh Indonesia. Problematika yang muncul penyelesaian perkara di bidang perceraian menggunakan pembuktian hukum acara perdata Barat, lebih mementingkan alat bukti formal, prosedural untuk menentukan perceraian para pihak di peradilan agama. 
ljtihad, Jurnal Wacana Hukum Islam dan Kemanusiaan, Volume 13, No. 1, Juni 2013: 105-124

\section{Pemberlakuan hukum acara perdata barat sebagai hukum acara peradilan agama.}

Sejak berlaku UU No.14 Tahun 1970 tentang Ketentuan Pokok-Pokok Kekuasaan Kehakiman, peradilan agama telah diakui sebagai subsistem peradilan Indonesia. Masyarakat Islam diberi ruang dan kesempatan untuk menyelesaikan perkara hukum keluarga berdasarkan hukum Islam. Asas personalitas beracara di peradilan agama adalah orang yang beragama Islam. Dalam perkembangannya, hal tersebut ditegaskan di dalam Pasal 1 UU No. 7 Tahun 1989 tentang Peradilan Agama.

Dalam kurun waktu Tahun 1970 hingga berlakunya UU No. 1 Tahun 1974 tentang Perkawinan pada tahun 1975, prakteknya hukum materiil dan hukum acara yang digunakan peradilan agama tidak aturan tertulis sebagai pedoman baku. Hakim peradilan agama menyelesaikan perkara berdasarkan tradisi dan paham yang berlaku di lingkungan masyarakat setempat. Prosedur penyelesaian perkara sangat bervariasi dan bergantung pada kemampuan ahli agama menterjemahkan, ketika yang bersangkutan ditunjuk dalam menyelesaikan perkara tersebut. Tidak ada panduan hukum acara yang terstruktur dan sistematis, maupun aturan hukum materiil yang tertulis sebagai panduan. (Republika, 6 Desember 2011). Namun satu hal yang menjadi catatan pada masa tersebut, proses penyelesaian perkara perceraian dapat dilaksanakan dengan hukum acara yang sederhana dan acara cepat, sehingga setiap perkara dapat diselesaikan tidak memakan waktu yang lama.

Pemberlakuan hukum acara perdata Barat secara mutatis mutandis di peradilan agama berdasarkan Pasal 54 UU No.7 Tahun 1989, telah menggiring penyelesaian perkara perceraian masuk ke dalam ranah hukum acara perdata Barat. Orientasi dan asas hukum acara perdata Barat bersifat mekanistik, ketika digunakan sebagai hukum acara peradilan agama khususnya acara perceraian, ternyata memunculkan berbagai persoalan. Pengajuan perkara perceraian dikondisikan melalui dua cara, yakni permohonan cerai dan cerai gugat. Dua cara tersebut ternyata menimbulkan persoalan dalam praktek, karena perkara perceraian sering digabung dengan perkara pengurusan anak dan harta benda hasil perkawinan.

Meningkatnya angka cerai gugat yang datang dari isteri, tidak lepas dari cara pandang hukum acara perdata Barat yang digunakan, sebab yang diperhatikan oleh setiap pikah yang mengajukan perceraian, lebih mementingkan aspek formalitas belaka, tidak ada keterkaitannya dengan norma agama. Padahal di dalam hukum perceraian Islam terdapat beberapa faktor 
yang harus diperhatikan sebagai dasar penyebab perceraian, serta menghendaki tatacara yang berbeda pula dalam pemeriksaan perkaranya. Aspek sakralitas yang berlandaskan pada keyakinan agama dalam penyelenggaraan maupun pembinaan hubungan perkawinan, mulai bergeser pada sisi mekanistik berdasarkan hukum acara perdata Barat yang berlaku di peradilan umum.

Persoalan hukum acara perceraian di peradilan agama yang dilakukan melalui permohonan cerai dan cerai gugat secara mutatis mutandis sebagai hukum nasional, ternyata telah mengalami gangguan (disturbance) dan pergeseran di dalam proses penegakannya. Penyebabnya adalah prosedur pengajuan perceraian, baik yang datang dari suami yang disebut permohonan ikrar talak, maupun perceraian yang datang dari isteri dengant cerai gugat. Motif perceraian lebih menonjol pada keinginan individual pasangan yang seringkali tidak didasarkan pada hal-hal yang bersifat prinsip.

Proses beracara di P.A yang lebih menonjol adalah sifat mekanistik prosedural, mulai dari permohonan atau gugatan, jawaban, replik, duplik, pembuktian, kesimpulan, upaya hukum dan eksekusi putusan yang lebih ditonjolkan tatacara pembuktian hukum acara perdata Barat. Aspek sakralitas sebagai pedoman utama dalam menyelesaikan perkara perceraian di P.A menghadapi dilema UU yang sangat mekanistik formal. Akibatnya setiap perkara perceraian yang masuk ke peradilan agama, baik permohonan cerai maupun cerai gugat dapat diprediksi hasilnya akhirnya adalah perceraian. Meskipun PERMA No.1 Tahun 2008 tentang Mediasi sebagai upaya mendamaikan para pihak yang berperkara cerai, tetapi keberhasilannya sangat kecil. Pergeseran orientasi budaya masyarakat yang melihat perceraian hanya sebagai proses peradilan dan terlepas dari aspek sakralitas berdasarkan keyakinan agama, ternyata sedang terjadi dan terus akan terjadi jika tidak ada usaha untuk merubah hukum acara peradilan agama yang berlaku berdasarkan Pasal 54 UU No. 7 Tahun 1989 tentang Peradilan Agama.

Beberapa hukum materiil yang mengalami gangguan (disturbance) dalam penegakannya, jika peradilan agama tetap menggunakan hukum acara perdata Barat, yakni: cerai gugat, pelanggaran taklik talaq, pencatatan perkawinan, tenggat waktu upaya hukum dalam sengketa cerai, eksekusi hak asuh anak, sengketa dengan pihak ketiga dalam perkara cerai \& kewarisan, asas personalitas dalam sengketa ekonomi syariah, Itsbat nikah (pengakuan nikah yang tidak 
ljtihad, Jurnal Wacana Hukum Islam dan Kemanusiaan, Volume 13, No. 1, Juni 2013: 105-124

tercatat), Ithbät cerai (perceraian yg tidak melalui Pengadilan Agama), upaya hukum perkara cerai dan pilihan hukum dalam sengketa kewarisan Islam.

Berdasarkan hal tersebut, jika peradilan agama menggunakan asas peradilan hukum acara perdata Barat yang menyatakan bahwa peradilan bersifat menunggu, maka dalam sengketa perkawinan seperti pelanggaran taklik talaq, itsbat nikah, itsbath cerai tidak dapat diatasi, apalagi jika menyangkut warga negara Indonesia beragama Islam yang berada di luar negeri. Selain itu hal yang terasa ganjil dalam proses pengucapan ikrar talak diberi kemungkinan untuk diberi kuasa kepada pihak lain untuk mengucapkan ikrar talaq di depan P.A sebagai akibat penggunaan hukum perdata Barat. Padahal ada batasan tidak semua perkara dapat diwakilkan pada penerima kuasa baik advokat maupun kuasa insidentil untuk dapat diwakilkan dalam perkara perceraian.

Kemudian upaya hukum dalam perkara perceraian baik upaya banding maupun permohonan kasasi, ternyata telah menambah persoalan yang cukup mengganggu. Jika menggunakan asas di dalam hukum Islam bahwa perkara cerai harus diselesaikan secara cepat, maka keberadaan upaya hukum terhadap perceraian sirasakan sangat mengganggu. Adanya upaya hukum dapat mengakibatkan status perkawinan seseorang menggantung dalam waktu bertehun-tahun tanpa kepastian hukum yang jelas. Bagi pihak perempuan sebagai isteri, baik sebagai penggugat maupun sebagai termohon cerai, adanya upaya hukum ternyata telah menimbulkan persoalan untuk menunggu kejelasan status perkawinan, maupun usaha untuk mendapatkan jodoh lain setelah bercerai. Meskipun upaya hukum dalam perkara perkara perceraian sangat sedikit jumlahnya, namun adanya upaya hukum juga dapat menjadi penyebab panjangnya proses perceraian yang harus dilalui seseorang di peradilan agama.

Usaha memperjuangkan hukum acara peradilan agama yang punya warna tersendiri untuk menyelesaikan hukum materiil di bidang hukum perceraian dan bidang lainnya sebagai hukum positif perlu dimulai oleh segenap komponen, baik akademisi, ulama, cendekiawan dan pemerhati di bidang peradilan agama.

\section{Hukum acara perdata barat dan peningkatan jumlah perceraian}

Jumlah angka perceraian di Indonesia yang masuk ke P.A setiap tahun cenderung meningkat. Melihat trend tersebut, perceraian seakan-akan menjadi solusi pertama, bukan 
solusi terakhir dalam penyelesaian perselisihan perkawinan. Ikatan perkawinan sebagai satu ikatan suci, sakral (mithaqan ghalidhan) yang menyatukan dua fisik dan perasaan berbeda, terlihat mulai bergeser (terjadi desakralisasi) yang hanya dilihat sebagai hubungan relasi pada dua pihak dan bersifat kebendaan belaka.

Berdasarkan data tercatat secara nasional pada tahun 2009 terjadi 250 ribu kasus perceraian. Jumlah perceraian tersebut meningkat signifikan jika dibandingkan tahun 2008 sebanyak 200 ribu kasus. Menurut Nasrudin Umar, angka tersebut setara dengan 10\% dari total jumlah pernikahan tahun 2009 sejumlah 2,5 juta. Perceraian terus meningkat dari 5-10 tahun lalu yang hanya sekitar 20-50 kasus per tahun. Peningkatan jumlah perceraian dilatarbelakangi makin longgarnya pemahaman dan penghayatan sendi rumah tangga. Patut dicatat $75 \%$ dari jumlah perceraian di P.A datang dari isteri (cerai gugat). Sebanyak $80 \%$ perceraian menimpa pasangan yang usia pernikahannya di bawah lima tahun. Apakah fenomena tersebut hanya bersifat sementara, ataukah sebagai suatu perubahan yang bersifat permanen. Fakta tersebut perlu diantisipasi, sebab keadaan tersebut tidak hanya dapat dijawab dari ketentuan UU saja, namun perlu ditinjau dari aspek lainnya, seperti pergeseran budaya keluarga dan perkembangan masyarakat (Republika, 6 Januari 2011). Meskipun pemerintah menyatakan terus berupaya menekan angka perceraian yang mengalami peningkatan setiap tahun, ternyata berhadapan norma hukum materiil dalam UU No.1 Tahun 1974 tentang Perkawinan yang memberikan rumusan syarat-syarat dan prosedur perceraian yang cenderung mekanistik formal (Republika, 8 Januari 2011). Peraturan Mahkamah Agung (PERMA) No.1 Tahun 2008 Tentang Mediasi dalam perceraian, ternyata belum mampu mencegah pasangan berperkara di P.A kembali berdamai dan rukun sebagai suami isteri.

Selanjutnya Nasruddin Umar menegaskan kunci utama keberhasilan mempertahankan rumah tangga keluarga harmonis, jika menegakkan sendi agama di dalam tumah tangga. Kuatnya pemahaman agama dam keyakinan dapat membentengi pengaruh luar yang merusak, seperti faktor infotainment yang secara vulgar mendemonstrasikan perceraian public figure. Di masa mendatang, diharapkan fenomena perceraian akan berkurang seiring kesadaran masyarakat tentang pentingnya keluarga sakinah. Di pihak lain Tuti Alawiyah menyatakan prihatin dengan angka perceraian yang kian meningkat. Perceraian akan menyisakan masalah, bukan hanya bagi orangtua (pasangan suami isteri yang bercerai), tetapi turut mengorbankan 
ljtihad, Jurnal Wacana Hukum Islam dan Kemanusiaan, Volume 13, №. 1, Juni 2013: 105-124

kepentingan dan masa depan anak-anaknya. Hal yang lebih penting adalah mempersiapkan proses perkawinan berlangsung lebih baik. Orangtua harus memberi pengarahan tentang arti dan tanggung jawab dalam kehidupan rumah tangga. Prinsipnya, menikah mesti didasari cinta, kasih sayang dan amanat serta "sakralitas harus kembali ditanamkan”. Hal yang paling utama pada keluarga perlu menekankan lagi penerapan nilai-nilai agama dalam kehidupan rumah tangga (Indah Wulandari: Bogor tanggal 9 Desember 2011). Berbagai faktor penyebab perceraian, seperti kesenjangan ekonomi, perselingkuhan, kecemburuan dan faktor lingkungan, dapat dihindari dengan menerapkan ajaran agama di keluarga (Republika, 21 Desember 2011). Apabila keduanya, baik suami maupun isteri saling pegang teguh agama, saling percaya, tidak cepat curiga, serta banyak bergaul dengan orang baik, insyaallah perceraian dapat dihindari.

Pendapat lain, Masyitoh Chusnan, Ketua PP Aisyiyah menyatakan telah terjadi pergeseran nilai keluarga dan hidup rumah tangga pada saat sekarang (Republika, 22 Desember 2011). Nilai-nilai keharmonisan rumah tangga yang dulu erat-erat dipegang kian terkikis. Kerapuhan iman disinyalir manjadi salah satu penyebab utama timbulnya perceraian. Langkah antisipasi adalah memperkuat fondasi agama di lingkungan keluarga. Ormas keagamaan diharapkan aktif berperan membarikan penyadaran dan penyuluhan pranikah kepada pasangan suami isteri, terutama bagi perempuan dan para remaja. Penyadaran diharapkan menyentuh pula pemahaman tentang UU kekerasan rumah tangga. Meskipun UU sebagai hukum negara di satu pihak mempunyai dampak positif, terutama dari nilai kepastian hukum (rechtszekerheids), namun di pihak lain diakui pula punya dampak negatif, dimana seringkali alasan mekanistik formal dan persoalan sepele dan diatur secara formal di dalam UU tersebut, pasangan baik suami atau isteri cenderung menempuh jalur hukum ke pengadilan. Padahal jika perceraian dipersepsikan sebagai jalan keluar terakhir, maka mestinya banyak upaya yang dapat dilakukan guna penyelesaikan sengekata suami isteri secara baik-baik tanpa harus bercerai.

Pendapat lain dikemukakan oleh Iffah Ainur Rochmah yang menyatakan lembaga perkawinan sebagai basis membangun keluarga telah mengalami disfungsi dan disorientasi. Pandangan yang mengutamakan pembangunan keluarga dipengaruhi sistem kapitalisme, ternyata berperan besar bagi kehancuran keluarga Indonesia. Akibatnya perpecahan keluarga yang tidak dapat dihindari tersebut, sehingga mempertinggi tingkat perceraian di Indonesia (Republika, 17 Desember 2011). 
Selanjutnya dikatakan disfungsi dan disorientasi terjadi, karena keluarga diposisikan sebagai institusi penunjang ekonomi rumah tangga. Banyak pernikahan hanya dipertahankan untuk alasan ekonomi terutama bagi pihak isteri. Di pihak lain Wahyu Widiana, menyatakan bahwa:

"Pada tahun 2001 angka perkara yang masuk ke peradilan agama berjumlah 171.335 perkara dan diputus sebanyak 159.299 perkara. Sementara pada tahun 2010 jumlah perkara yang masuk ke peradilan melonjak menjadi 320.788 perkara dan perkara yang diputus 295.589 perkara. Jumlah perkara yang tertunggak pada tahun 2011 berjumlah 25.199 perkara. Artinya dalam sepuluh tahun terjadi lonjakan perkara yang sangat signifikan" (Republika 27 Desember 2011).

Di satu pihak Wahyu Widiana menilai lonjakan perkara tersebut bukan imbas dari era reformasi, namun sebagai wujud keasadaran hukum masyarakat terutama kaum perempuan, karena umumnya perkara cerai datang dari isteri dalam bentuk cerai gugat (kbulu), Kemudian Wahyu Widiana tidak sependapat dengan pemikiran bahwa lonjakan gugatan cerai dari perempuan sebagai akibat dari faktor ekonomi, sebab berdasarkan temuannya banyak juga perempuan yang menggugat cerai suaminya adalah orang-orang yang keadaan ekonomi keluarganya baik dan mapan. Ditegaskannya kebanyakan perempuan yang mengajukan gugatan cerai adalah dizalimi oleh suaminya (Bogor tanggal 9 Desember 2011). Namun hal yang dilupakan bahwa hak talak yang secara agama Islam adalah hak laki-laki, tetapi seolaholah dikaburkan. Selain itu jika alasan isteri yang menggugat suami adalah dizalimi tentunya semua dapat dibantah, sebab pada saat sekarang juga banyak isteri yang mendzalimi suaminya.

Mahkamah Agung menggambarkan data perkara yang terdaftar di P.A secara nasional hingga tahun 2010, tercantum dalam Tabel 1 berikut: 
ljtihad, Jurnal Wacana Hukum Islam dan Kemanusiaan, Volume 13, No. 1, Juni 2013: 105-124

\section{Tabel 1}

\section{Data Perkara P.A secara Nasional Tahun 2010}

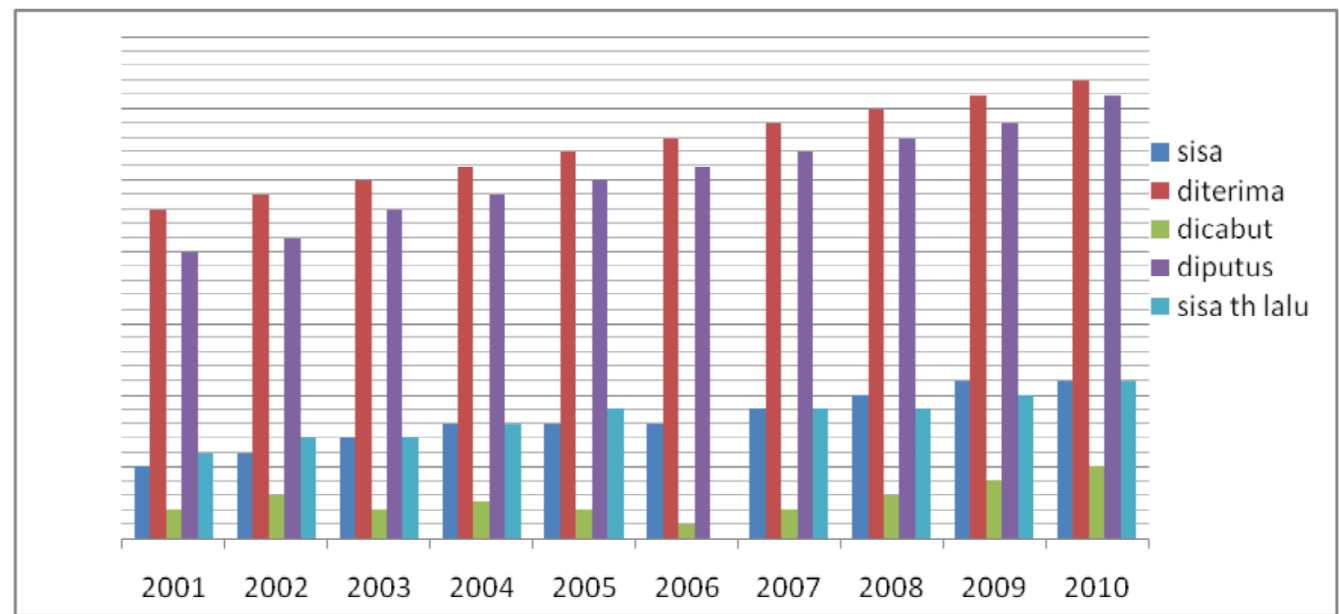

Berdasarkan gambaran data dari Tabel 1, terlihat dalam sepuluh tahun terakhir jumlah perkara di P.A terus meningkat secara signifikan. Umumnya alasan perceraian terjadi didasarkan pada alasan yang tidak masuk dalam lingkup perbedaan prinsip, tetapi lebih didasarkan pada kepentingan duniawi.

Pada tahun 2010 penyebab utama terjadinya perceraian adalah masalah ekonomi $(23,8 \%)$, perselingkuhan $(7,07 \%)$, cemburu $(3,52 \%)$, kekerasan fisik $(0,77 \%)$, sisanya perkawinan lintas agama dan lintas negara, pernikahan di bawah umum serta perkawinan tanpa dilandasi rasa cinta. (Republika, 21 Desember 2011). Padahal berdasarkan hasil penelitian yang tidak dilandasi faktor agama, bahwa prediksi adanya kebahagiaan bagi seseorang (predictor of happiness) ditentukan dari pernikahan dan hadirnya anak, dimana sebanyak 42\% perempuan menyatakan bahagia dengan menikah, sedangkan laki-laki 37\% menyatakan bahagia dengan manikah. Setelah lembaga pernikahan, hal yang menjadi kebahagiaan seorang adalah pekerjaan serta struktur kepribadian diri sendiri.

Mahkamah Agung menggambarkan angka perceraian yang terjadi pada tahun 2010 di lima wilayah hukum Pengadilan Tinggi Agama di Indonesia sebagai berikut: 
Tabel 2

Angka Perceraian di Lima Pengadilan Tinggi di Indonesia Tahun 2010

\begin{tabular}{cccccc}
\hline No & PTA & $\begin{array}{c}\text { Jumlah } \\
\text { Kasus }\end{array}$ & Ekonomi & $\begin{array}{c}\text { Tidak } \\
\text { Harmonis }\end{array}$ & $\begin{array}{c}\text { Tidak Tanggung } \\
\text { Jawab }\end{array}$ \\
\hline 1 & Bandung & 76.878 & 33.684 & 25.846 & 17.348 \\
\hline 2 & Surabaya & 68.092 & 12.326 & 22.766 & 17.032 \\
\hline 3 & Scmarang & 54.105 & 12.019 & 13.904 & 21.684 \\
\hline 4 & Makassar & 7.673 & 802 & 2.476 & 1.691 \\
\hline 5 & Jakarta & 7.303 & 1.437 & 1.933 & 1.685 \\
\hline
\end{tabular}

Sumber data; Mahkamah Agung R.I.

Berdasarkan data Mahkamah Agung (MA) R.I tersebut, secara garis besar terdapat 4 (empat) faktor penyebab perceraian pasangan suami isteri yaitu Pertama, masalah Moral yang dikategorikan pada poligami tidak sehat. Terjadi poligami tanpa melalui prosedur yang ditentukan UU, tanpa ada persetujuan dari isteri (isteri-isteri) terdahulu yang dikuatkan penetapan Pengadilan Agama. Poligami terjadi karena krisis akhlak, tetapi tanpa ada rincian batasan yang jelas tentang krisis akhlak, baik dari aspek agama dan keyakinan.

Kedua, meninggalkan kewajiban, diklasifikasi bila pasangan menikah karena ada unsur kawin paksa, antar pasangan tidak muncul kesepakatan dan sukarela. Selain itu perceraian terjadi karena faktor ekonomi dan penghasilan tetap sebagai masalah inti terjadi perceraian. Kemudian faktor tidak bertanggung jawab, juga penyebab terjadi perceraian. Tanggungjawab ditujukan kepada suami, karena mempunyai kewajiban memberi nafkah lahir dan batin. Padahal tanggungjawab pun dituntut kepada isteri untuk memenuhi kewajiban sebagai isteri dan ibu rumah tangga.

Ketiga, menyakiti jasmani/rokhani; Mahkamah Agung R.I membagi perceraian dengan alasan menyakiti pasangan, baik menyakiti jasmani, cacat fisik atau melakukan penganiayaan yang berakibat terganggunya aktivitas secara normal, baik di bidang pekerjaan maupun dari aspek biologisnya. Menurut catatan KOMNAS Perempuan pada tahun 2010, perempuan korban kekerasan sebanyak 105.103 orang. Sebanyak 101.128 orang atau 96\% adalah perempuan korban kekerasan dalam rumah tangga/relasi personal (KDRT/RP). Kekerasan terhadap perempuan di ranah komunitas sebanyak 3.530 orang dan kekerasan di ranah 
ljtihad, Jurnal Wacana Hukum Islam dan Kemanusiaan, Volume 13, No. 1, Juni 2013: 105-124

negara sebanyak 445 orang (Teguh Firmansyah dalam Republika, 23 Desember 2011). Sementara menyakiti mental, setidaknya pasangan suami isteri membuat secara psikis terganggu baik dalam berkomunikasi secara verbal di muka umum, maupun dalam bentuk lainnya. Berdasarkan laporan 383 Lembaga Mitra Pengada Layanan yang tersebar dari Nangroe Aceh Darussalam hingga Papua, bahwa kekerasan terhadap isteri (KTI) berjumlah 98.577 orang (terdiri dari kekerasan psikis 86.682 orang, alasan ekonomi 6806 orang, fisik 3,028 orang serta lainnya 122 orang), kekerasan dalam pacaran (KDP) berjumlah 1.299 orang, kekerasan terhadap anak perempuan (KTAP) berjumlah 660 serta oleh mantan suami (KMS) dan kekerasan mantan pacar (KMP) berjumlah 592 orang. Kemudian salah satu pihak mendapat hukuman pun menjadi dasar perceraian.

Keempat, terus menerus berselisih, Mahkamah Agung membagi perceraian terjadi dengan alasan politis. Pasangan suami isteri dapat bercerai karena antara keduanya mempunyai partai politik yang berbeda. Pada era otonomi daerah dengan multi partai, tuntutan untuk diakui aktualisasi diri, baik laki-laki dan perempuan adalah sama. Terdapat pasangan suami isteri yang punya partai politik dan ideologi yang berbeda, akibatnya hal-hal yang bersifat publik terbawa ke dalam rumah tangga sebagai penyebab perceraian. Langgengnya rumah tangga, jika pasangan saling menghormati dan berkomitmen untuk setia dan sayang. Munculnya pihak ketiga dan luntur komitmen berakibat terjadi perceraian.

Tinggi dan meningkatnya angka perceraian di setiap Pengadilan Agama, dapat dijadikan dasar sebagai alasan di dalam UU hukum acara dan aturan pelaksana, tidak dipandang mekanistik formal saja. Meskipun berbagai pihak melihatnya meningkatnya angka perceraian sebagai faktor meningkatnya kesadaran hukum termasuk Kementrian Agama R.I, namun sebagai benteng tegaknya aturan terletak pada kinerja hakim Pengadilan Tinggi Agama dan P.A yang cenderung mudah menyetujui gugatan perceraian (Republika, 9 Agustus 2011). Nasruddin Umar menegaskan, hakim peradilan agama ke depan dapat memberi kesempatan mediasi dengan waktu yang cukup kepada kedua pihak yang berselisih dengan memberikan peluang dan waktu yang cukup pada proses mediasi, bahwa pihak yang berselisih untuk rujuk sebagai suami isteri.

Melihat fakta dan perkembangan perceraian yang terus meningkat setiap tahun, maka UU No. 1 Tahun 1974 tentang Perkawinann telah beberapa kali diusulkan untuk direvisi. 
Terakhir telah mengajukan uji materiil terhadap Pasal 39 Ayat (2) dan Pasal 19 Huruf (f) Peraturan Pemerintah No. 9 Tahun 1975 ke Mahkamah Konstitusi. Halimah Agustina Kamil pada tahun 2011 telah mengajukan Uji materiil terhadap rumusan alasan perceraian perselisihan secara terus menerus, sebab cenderung berlaku secara subjektif (Republika, 9 Agustus 2011). Pasal 39 Ayat (2) UU Nomor 1 Tahun 1974 memuat tentang alasan untuk putusnya perceraian, yaitu "antara suami isteri tidak dapat bidup rukun sebagai suami isteri". Dalam penjelasan UU, disebutkan enam alasan yang dapat dijadikan dasar perceraian, salah satu pihak mendapat hukuman penjara lima tahun atau hukuman lebih berat setelah perkawinan berlangsung, melakukan zina, pemabuk, penjudi, pemadat, meninggalkan pihak lain selama dua tahun berturutturut tanpa izin dan alasan yang sah, salah satu pihak melakukan kekejaman atau penganiayaan berat yang membahayakan terhadap pihak lain, salah satu pihak mendapat mendapat cacat badan atau penyakit sehingga tidak dapat menjalani kewajiban sebagai suami/isteri.

Selanjutnya di dalam Pasal 19 huruf (f) Peraturan Pemerintah No. 9 Tahun 1975 alasan perceraian disebutkan bahwa antara suami dan isteri terus menerus terjadi perselisihan dan pertengkaran dan tidak ada harapan hidup rukun lagi. Menurut Makarim Wibisono sebagai saksi di depan sidang Mahkamah Konstitusi, pasal tersebut sangat merugikan kaum perempuan dan berpotensi merugikan para isteri (Kompas, 11 Agustus 2011). Selanjutnya Makarim Wibisono menyatakan, alasan sebagaimana tercantum di dalam huruf (f) bertentangan dengan konsep hak asasi manusia. Konsep tersebut bertumpu bahwa semua orang sama dan tidak ada bedanya. Konsep HAM tidak membenarkan adanya diskriminasi dalam bentuk apapun karena etnis, ras, jender, pendidikan, kekayaan, warna kulit, agama, pekerjaan, dan kondisi fisik seseorang. Lebih lanjut dikatakan "Konsep huruf (f) merugikan isteri, karena tidak memberikan keadilan yang mencerminkan tidak ada persamaan hak kaum perempuan dan isteri dengan hak suami”.

Para suami dapat dengan mudah menceraikan isteri dengan alasan terus terjadi perselisihan, karena ketentuan tersebut tidak meminta kejelasan tentang siapa pemicu atau apa yang menjadi penyebabnya. Menurut Makarim Wibisono hal tersebut tidak adil. Alasannya, isteri yang membangun rumah tangga atas dasar cinta tidak dapat menerima bila suaminya memiliki hubungan dengan perempuan lain. Pandangan tersebut jelas sangat berbeda dengan nilai hukum Islam, sebab secara kelembagaan perkawinan tidak hanya domain hak pasangan, 
ljtihad, Jurnal Wacana Hukum Islam dan Kemanusiaan, Volume 13, No. 1, Juni 2013: 105-124

tetapi keduanya harus pada aturan agama yang mengaturnya.

Ketika terjadinya silang pendapat dan tarik menarik pendangan tentang ternd peningkatan perceraian, maka hukum acara peradilan agama perlu dilakukan pembaharuan melalui proses legislasi, yakni melahirkan UU hukum acara peradilan agama nasional. Hal tersebut sangat penting, sebab jika tetap menggunakan hukum acara perdata Barat sebagai hukum acara peradilan agama di bidang perceraian, maka hakikat perceraian hanya diukur dari proses dan tahapan perkara saja, tidak ada kaitannya dengan unsur kesadaran mempertahankan perkawinan dari sisi hukum agama.

\section{Problematika eksekusi hak asuh anak (hadanah) akibat perceraian}

Tugas P.A dalam menyelesaikan perkara perceraian, tidak terbatas memutuskan hubungan dan ikatan perkawinan, melainkan juga terhadap hal-hal yang mengikuti putusan, baik menyangkut hak asuh anak dan harta benda sebagai harta bersama selama perkawinan berlangsung. Permasalahan di P.A tentang eksekusi hak asuh dan jaminan hidup (badanah) terhadap anakanak, menyangkut dua hal. Pertama tentang eksekusi putusan yang telah mempunyai kekuatan hukum tetap dari P.A sebuah pengadilan negara. Kedua, tentang keadilan putusan dilihat dari sudut hukum Islam yang sepatutnya memutus perkara berdasarkan hukum Islam.

Hadanah atau hidanah secara bahasa berarti ja'alahu fi hadnibi (menjadikan dalam pelukan) atau șana'ahu fi sadribi (menempatkannya di dada). Hadanah al-tifl adalah memeluk dan merangkul anak tersebut dalam rangka untuk melindunginya. Dengan demikian, ḥadanah adalah pengasuhan sehingga dikatakan al-wilāyah 'ala al-tifl li tarbiyatibi wa tadbiri shu'unibi (pewalian atas anak untuk tujuan mendidik dan mengurus urusannya). Definisi lain menyatakan bahwa Custody is to nurture a child who is unable to take care of him/ herself during certain ages by somebody who cannot get married to that cbild. Artinya, hadanah adalah mengasuh anak yang tidak mampu mengurus dirinya sendiri dalam usia-usia tertentu oleh orang yang tidak dapat kawin dengan anak tersebut (Rifyal Ka'bah: 2007).

Dalam sistem hukum di dunia terdapat beberapa bentuk pengasuhan seperti diungkapkan oleh Rifyal Ka'bah sebagai berikut ini.

Pertama, devided custody (pengasuhan terbagi), di mana salah satu orang tua, baik ayah maupun ibu, memiliki pengasuhan fisik dan tanggungjawab sepenuh waktu terhadap anak. Kedua, joint custody (pengasuhan bersama), yaitu pengaturan di mana kedua orang 
tua sama bertanggungjawab dan mempunyai kekuasaan terhadap anak, tetapi pengasuhan fisik berada di tangan salah seorang dari mereka. Pengasuhan fisik diberikan kepada ayah atau ibu, sedangkan masalah pendidikan, agama anak dan lainnya ditentukan bersamasama. Ketiga, physical custody (pengasuhan fisik), yaitu hak yang diberikan pengadilan kepada salah satu orang tua untuk mengasuh anak, baik ibu maupun ayah. Anak secara fisik tinggal bersama salah seorang dari orang tua, tetapi masa depan anak, biaya hidup, tidak ditangani sendiri oleh pihak pengasuh secara fisik. Keempat, sole custody (pengasuhan sepenuhnya), yaitu pengaturan orang memiliki kontrol penuh terhadap anak dan pembuat keputusan terhadap anak, pengasuhan penuh diberikan kepada ibu atau kepada ayah (Ka'bah, 2007).

Berdasarkan dari empat jenis pengasuhan tersebut tampak bahwa antara ibu dan ayah, atau salah satunya, sama-sama mempunyai hak untuk mengasuh anak tergantung ketentuan legislasi yang ada dalam satu negara atau putusan pengadilan. Hukum Islam menyatakan bahwa di saat terjadi perceraian, maka anak yang masih di bawah umur diasuh oleh ibunya dan biaya hidup ditanggung oleh ayah. Ketentuan tersebut diadopsi oleh peraturan perundang-undangan dan praktek peradilan di Indonesia. Hal demikian karena itulah yang lebih dekat kepadanya dan lebih mampu menjaganya secara alami, sebab dibanding dengan ayah, maka ibu lebih mempunyai rasa kasih, sayang dan berkualifikasi.

Banyak persoalan yang timbul di lapangan mengenai masalah hadanah:

Permasalaban pertama, adalah perceraian sendiri yang membawa dampak terhadap pengasuhan anak. Dilihat dari aspek psikologis perkembangan anak, jika dalam satu keluarga yang bercerai mempunyai anak, maka sangat banyak jumlah generasi muda ke depan hilang moment golden age dan memiliki mental tidak stabil akibat perceraian orangtuanya. Upaya terbaik untuk memecahkan persoalan adalah menjaga keutuhan keluarga dengan mencegah perceraian. Lembaga perkawinan sebagai gerbang terbentuknya keluarga yang merupakan inti masyarakat dan negara, hendaknya bukan hanya dilihat seremonial formal belaka. Hal tersebut merupakan tugas masyarakat dan negara secara umum, terutama menyangkut tugas peradilan. P.A yang sejak dahulu telah mengenal lembaga tahkim (perdamaian, arbitrasi perkawinan), di dalam setiap putusan pengadilan selalu dinyatakan hakim telah berupaya mendamaikan para pihak, tetapi tidak berhasil. Dalam praktek sekarang, media tahkim (mediasi) ternyata hanya digunakan sebagai upaya basa-basi saja dan belum dilakukan secara maksimal untuk mengakhiri perkara perceraian. Peradilan Agama dapat mencontoh sistem 
ljtihad, Jurnal Wacana Hukum Islam dan Kemanusiaan, Volume 13, No. 1, Juni 2013: 105-124

peradilan di negara lain seperti Jepang, Australia dan Amerika Serikat yang membuka dua pintu pada semua lembaga peradilan dengan mekanisme jelas dan diatur oleh UU. Setiap pencari keadilan pertama kali diarahkan untuk memasuki pintu pintu perdamaian sebelum masuk ke pintu kedua yang merupakan proses litigasi. Pintu litigasi hanya dibuka, jika usaha maksimal mediasi tidak berhasil. Setiap pintu mempunyai mekanisme jelas dan aparat profesional yang berusaha maksimal mengarahkan pihak-pihak untuk berdamai, tidak hanya terdiri dari hakim khusus pendamai, juga ahli kemasyarakatan, ahli pendidikan dan ahli psikologi. Hasil perdamaian dan arbitrase akan membawa kepada win-win-solution dan hasil litigasi berarti menang dan kalah. Peradilan agama mempunyai hukum acara untuk litigasi, sedangkan hukum acara lengkap perdamaian belum maksimal. Belum adanya hukum acara khusus dan pedoman praktis, menghendaki hakim P.A untuk berusaha mengaktifkan lembaga tahkim, sehingga kasus perceraian dapat dikurangi dan dengan juga mengurangi masalah hadanah akibat perceraian.

Permasalahan kedua adalah kesulitan dalam eksekusi putusan ḥadanah, khususnya bila sang anak tidak berada di tangan pihak yang memenangkan hak hadanah. Berbeda dengan eksekusi perkara kewarisan, karena menyangkut benda, maka pelaksanaannya dapat dipaksakan dengan melibatkan pihak keamanan, terutama polisi. Sedangkan pada eksekusi anak tidak mungkin dipaksakan, karena menyangkut perasaan anak, terutama untuk kepentingan anak (for the best interest of the child), baik dari syariat Islam maupun dari peraturan perundang-udangan. Tidak adanya sanksi dan sulit dibuat sanksi, jika ada pihak tidak mau menyerahkan anak yang ada di tangannya kepada pihak yang memenangkan hak ḅadanah, juga merupakan hal sulit untuk dijabarkan di dalam praktek.

Permasalahan ketiga, putusan hadanah di P.A belum sepenuhnya sesuai dengan hukum Islam. Di dalam KHI maupun praktek peradilan agama, haḍanah anak di bawah umur diberikan kepada ibu, kecuali kalau ibu murtad, maka ḥadanah dipindahkan kepada ayahnya. Yurisprudensi Mahkamah Agung belum mengatur pemindahan ḥadanah jika ibunya menikah lagi. Dalam hal ibu dipandang tidak cakap memegang hadanah anak, maka hakim P.A biasanya menyerahkan ḥadanah kepada ayah. Hukum Islam melalui fiqh para fuqaha' telah membuat urut-urutan orang yang berhak memegang hadanah anak di bawah umur setelah ibu kandung kawin, meninggal dunia atau tidak berkualifikasi. 


\section{Pentingnya hukum acara perceraian peradilan agama nasional}

Hukum acara perdata Barat yang berlaku di peradilan umum dan diadopsi oleh peradilan agama sebagai hukum acara adalah hasil kodifikasi pada abad ke 19. Konsep yang diusung adalah individualis dan bersifat sekuler. Baik H.I.R (Het Herziene Inlands Reglement), R.Bg (Rechtsreglement Buiten Gewesten) maupun B.Rv (Burgelijke Recbtvoordering), adalah dibuat untuk mengabdi kepada hukum materiil Barat, yakni BW (Burgelijke Wetboek), W.v.K (Wetboek van Koephande). Dasar pijakan yang dijadikan objek perkara dalam hukum perdata Barat adalah benda (zaak). Di dalam proses perkara di peradilan dapat digunakan sita jaminan (conservatoir beslag). Proses penyelesaian perkara pasca putusan telah memperoleh kekuatan hukum tetap (Inkracht van gewijsde), dapat dilakukan sita eksekusi sesuai materi putusan.

Berbeda dengan perkara yang masuk kewenangan peradilan agama, bahwa perkaranya menyangkut bidang hukum keluarga (ahwal shakbsiyyah) yang diatur menurut agama Islam. Baik perkara yang berbentuk perceraian, kewarisan, hibah, zakat, maupun ekonomi syariah, semuanya dilandasi pada kebenaran dan keadilan menurut ukuran hukum Islam. Tidak semua kebenaran dapat diukur dari asas kepastian sebagaimana diatur dalam rumusan pasal UU. Sesuai dengan asas hukum, bahwa hukum pada tataran norma bersifat netral dan kebenarannya diakui. Namun ketika norma diberi bentuk UU, maka muncul kepentingan para pembuat yang menyebabkan norma hukum yang tidak lagi netral. Apalagi jika dihubungkan dengan hukum acara perdata Barat yang dibuat menurut konsep legalisme dan positivis, maka hukum acara tersebut sakma sekali tidak peduli dengan kebenaran berdasarkan hukum Islam. Artinya, ketika UU peradilan agama mengamanatkan menggunakan hukum acara perdata Barat untuk menyelesaikan perkara perceraian, maka sejak saat itu masyarakat secara sadar telah digiring untuk mengukur kebenaran hukum materiil berdasarkan hukum Islam, menggunakan parameter hukum Barat. Khusus sengketa perkawinan dalam perkara perceraian merupakan pintu masuk (entry point) untuk menyelesaikan beberapa hal yang mengikutinya. Tidak saja terhadap kepentingan para pihak yang berperkara untuk memutuskan ikatan perkawinan, tetapi terhadap hal-hal sebagai ikutan dalam perceraian, baik menyangkut harta benda, kepentingan pengasuhan anak. Anak tidak dapat diletakkan objek sita maupun eksekusi, sebab anak adalah subjek hukum. Oleh karena anak di dalam perkawinan juga adalah subjek hukum, maka eksekusi putusan perkara perceraian 
ljtihad, Jurnal Wacana Hukum Islam dan Kemanusiaan, Volume 13, No. 1, Juni 2013: 105-124

memunculkan permasalahan dalam penerapannya.

Sebagai pemikiran bahwa pemberlakuan UU No. 7 Tahun 1989 tentang Peradilan Agama dan telah mengalami dua kali perubahan, yakni UU No. 3 Tahun 2006 dan UU No. 50 Tahun 2009, belum terpikirkan secara serius untuk menggagas melahirkan UU tentang hukum acara khusus peradilan agama. Apabila keadaan seperti sekarang dibiarkan, maka munculnya perkara perceraian bukan hanya terus meningkat, tetapi lembaga perkawinan bergeser kapada pandangan desakralitas yang menganggap perkawinan dan perceraian dapat dilakukan kapan saja berdasarkan selera masing-masing individu. Jika tidak dapat mewujudkan UU nasional dikarenakan sulitnya untuk menerobos kepentingan politik di DPR, setidaknya ada usaha untuk menyederhanakan ketentuan di alam H.I.R dan R.Bg untuk disesuaikan dengan norma materiil hukum Islam menyangkut bidang perceraian

\section{Penutup}

Berdasarkan urian dalam pembahasan, dapat disimpulkan tentang hal-hal sebagai berikut: Pertama, pemberlakuan hukum acara perceraian di peradilan agama yang secara normatif mutatis mutandis masih menggunakan hukum acara peradilan umum, telah membawa polarisasi dan bias nilai, asas-asas, norma maupun proses aktualisasinya. Ketika diterapkan sebagai hukum acara perceraian di lingkungan peradilan agama, maka hukum acara Barat menggeser kerakteristik yang melekat pada hukum materiil sebagai dasar kewenangan peradilan agama. Praktek peradilan agama lebih mengutamakan penyelesaian berdasarkan nilai-nilai hukum Islam, yakni mengutamakan aspek manfaat dan kebaikan bagi para pihak yang berperkara demi kemashlahatan.

Kedua, hukum acara perceraian peradilan agama yang menggunakan hukum Barat memunculkan tahapan penyelesaian perkara perceraian bersifat teknis dan tekstual semata. Implikasinya pemutusan perceraian dan akibatnyahanya dilihat dari teknis peradilan, mengesampingkan sisi sakralitas yang menjadi ciri utama kewenangan yang diberikan kepada P.A dalam menyelesaian perkara umat Islam. 


\section{Daftar pustaka}

Ahmad Rofiq. Hukum Islam di Indonesia. cet. 4, Jakarta: Raja Grafindo Persada, 2000.

Alawy, Zainal Abidin. Ijtihad Kontemporer dan Reformasi Hukum Islam dalam Perspektif Mahmud Syaltut, Jakarta: Yayasan Haji Abdullah Amin, 2003.

Ali, H. Mohammad Daud. Hukum Islam: Pengantar Ilmu Hukum dan Tata Hukum Islam di Indonesia. Jakarta:Raja Grafindo Persada, 1996.

Ali, H. Mohammad Daud. Peradilan Agama (Kumpulan Tulisan). Jakarta: Rajawali Press, 1995.

Anshori, Abdul Ghofur. Peradilan Agama di Indonesia Pasca UU Nomor 3 Tahun 2006. Cetakan 1, Yogyakarta: UII Press, 2007.

Basyir, Achmad Azhar. Hukum Perkawinan Islam. Yogyakarta: Universitas Islam Indonesia, 1977.

Bek, Ahmad Ibrahim. et.al., Ahkam al-Ahwal asy-Syakhshiyyah fi asy-Syari'ab al-Islamiyyah. Cairo: n.p., 2003.

Bruggink, J.H.H. Rechtsreflecties, Grondbegrippen uit de Rechrtheorie. terjemahkan oleh Bernard Arief Sidharta. Refleksi tentang Hukum. Bandung: Citra Aditya, 1996.

Gerven, W. An. Kebijaksanaan Hakim. Jakarta: Erlangga, 1990.

Harahap, M. Yahya. Hukum Acara Perdata Tentang Gugatan, Persidangan, Penyitaan, Pembuktian dan Putusan Pengadilan. cetakan kedua. Jakarta: Sinar Grafika, 2005.

Hazairin. Demokrasi Pancasila. Jakarta: Rineka Cipta, 1990.

Jazuni. Legislasi Hukum Islam di Indonesia. Bandung: PT.Citra Adtya Bakti, 2005.

Ka'bah, Rifyal. Hukum Islam di Indonesia: Perspektif Muhammadiyah dan N.U. Jakarta: Universitas Yarsi, 1999.

Lili Rasjidi dan B.Arief Sidharta. Filsafat Hukum, Mą̧ab dan Refleksinya. Bandung: Remaja Rosdakarya, 1994.

Mardani. Hukum Acara Perdata Peradilan Agama \& Mabkamah Syariah. cetakan pertama, Jakarta: Sinar Grafika, 2009.

Mertokukuso, Soedikno. Hukum Acara Perdata Indonesia. cet.-ketujuh Yogyakarta: Liberty, 1998.

Muhammad, Abdul Kadir. Hukum Acara Perdata Indonesia. Bandung: Alumni, 1978.

Praja, Juhaya S. Sejarah dan Perkembangan Hukum Islam. Bandung: Penerbit PT Remaja Rosdakarya, cetakan pertama Maret 2000.

Projodikoro, Wirjono. Hukum Acara Perdata di Indonesia. Bandung: Sumur Bandung, 1962.

Rahardjo, Satjipto. Penegakan Hukum Progresif. Jakarta: Alvabet, 2004.

Rahardjo, Satjipto. Hukum dan Perubahan Sosial. Bandung: Alumni, 1993. 
ljtihad, Jurnal Wacana Hukum Islam dan Kemanusiaan, Volume 13, No. 1, Juni 2013: 105-124

Ramulyo, M.Idris. Beberapa Masalab tentang Hukum Acara Perdata Peradilan Agama dan Hukum Perkawinan Islam, Jakarta: Ind-Hell Co, 1985

Sjadzali, Munawir. "Landasan Pemikiran Politik Hukum Islam dalam Rangka Menentukan Peradilan Agama". dalam Tjun Suryaman (ed), Hukum Islam di Indonesia Pemikiran dan Praktek, cetakan kedua, Bandung: 1994.

Soekanto, Soerjono dan Sri Mamudji. Penelitian Hukum Normatif. Jakarta: Rajawali Press, 1985.

Sukardja, Ahmad. Piagam Madinan dan UU dasar 1945, Kajian Perbandingan tentang dasar Hidup Bersama dalam Masyarakat yang Majeluk. Jakarta: UII Press, 1995.

Utrech E. Pengantar Dalam Hukum Indonesia. Jakarta: Pradnya Paramita, 1960. 